\title{
Analisis Kinerja Sistem Informasi Akademik Menggunakan Metode TRADE Pada Universitas Tridinanti Palembang
}

\author{
Ahmad Faizal ${ }^{1}$, Rusmala Santi ${ }^{2}$, Catur Eri Gunawan ${ }^{3}$ \\ 1,2,3Sistem Informasi, Fakultas Sains dan Teknologi, UIN Raden Fatah Palembang, Indonesia \\ Email:1ahmad.faizal2007@gmail.com, 2rusmalasanti_uin@radenfatah.ac.id, \\ ${ }^{3}$ caturerig@radenfatah.ac.id
}

\begin{abstract}
Palembang Tridinanti University has an academic information system created with the aim to facilitate lecturers, students and employees in the lecturing process of Tridinanti University in Palembang. then it needs to be reviewed to analyze the performance of academic information systems at Tridinanti University, Palembang. Therefore it is necessary to hold performance measurements to find out whether the academic information system is in accordance with what is expected. The measurement methods used are observation, interviews, questionnaires, and documentation. Then performance measurements are carried out to determine the performance of the running system using the method of performance measurement according to Training Resources Data Exchange (TRADE). The results of this study are used as recommendations for improvement so that the performance of the academic information system at Palembang's Tridinanti University can run according to the target.
\end{abstract}

Keywords: Performance Analysis, Academic Information Systems, System Performance Measurement, Training Resources Data Exchange (TRADE)

\section{PENDAHULUAN}

Kata Kinerja sistem informasi merupakan penilaian terhadap pelaksanaan sistem tersebut, apakah sudah sesuai dengan tujuan yang telah ditetapkan atau belum. (Soegiharto, 2001:26) Kinerja sistem informasi merupakan bagian dalam teknologi informasi yang bertujuan memberikan berbagai kemudahan untuk memperoleh suatu informasi, Penggunaan teknologi sistem informasi pada organisasi saat ini telah mengalami peningkatan. bahwa penggunaan sistem dalam organisasi meningkat secara drastis. Peningkatan ini selain dikarenakan tuntutan organisasi modern, juga disebabkan oleh masyarakat yang harus akan informasi.Salah satu produk teknologi informasi yang banyak 


\section{Journal of Software Engineering Ampera}

Vol. 1, No. 1, February 2020 e-ISSN: 2775-2488

https://journal-computing.org/index.php/journal-sea/index

dimanfaatkan oleh berbagai instansi baik swasta, pemerintah ataupun bidang pendidikan adalah sistem informasi.

Penggunaan sistem informasi sangat membantu dalam kegiatan operasional instansi karena sistem informasi membuat data dan informasi yang diperlukan lebih mudah untuk diperoleh. Contoh implementasi sistem informasi dalam lingkungan perguruan tinggi yaitu sistem informasi akademik. Salah satu perguruan tinggi di kota Palembang yang telah memanfaatkan teknologi informasi adalah Universitas Tridinanti Palembang. Universitas Tridinanti Palembang telah menerapkan sebuah sistem informasi akademik untuk menyajikan informasi dan menata administrasi yang berhubungan dengan kegiatan akademis. Sistem ini diharapkan dapat mengelola data administrasi akademis dengan baik dan informasi yang diperlukan dapat diperoleh dengan mudah dan cepat.

Mengingat sudah lamanya diterapkan sistem informasi akademik pada Universitas Tridinanti Palembang maka perlu dilakukan evaluasi untuk mengetahui sejauh mana kinerja sistem informasi akademik Universitas Tridinanti Palembang. Pentingnya dilakukan evaluasi terhadap suatu sistem informasi adalah untuk mengetahui apakah sistem informasi yang diterapkan dan dihasilkan sudah sesuai dengan yang diharapkan dan dibutuhkan pengguna dan apakah tujuan dari dibangunnya sistem informasi akademik sudah tercapai atau belum. Berkaitan dengan kinerja sistem, kinerja sistem informasi tidak hanya ditentukan oleh bagaimana sistem dapat memproses dan menghasilkan informasi dengan baik, tetapi bagaimana aspek-aspek pada kinerja sistem sudah sesuai dengan apa yang diharapakan oleh pengguna sistem. Analisis pengukuran kinerja penting untuk dilakukan karena evaluasi dari para pengguna dalam berinteraksi langsung dengan sistem, sehingga data yang diharapkan sesuai dengan kebutuhan para pengguna, dan dapat digunakan untuk mengetahui kelemahan-kelemahan proses pada implementasi system(Jogiyanto, 2008).

Ada beberapa metode analisis kinerja ialah Balanced Scorecard merupakan kartu skor yang digunakan untuk mengukur kinerja dengan memperhatikan keseimbangan antara faktor keuangan dan non-keuangan baik jangka pendek maupun jangka panjang serta kondisi internal maupun eksternal, kemudian metode Performance Prism adalah metode pengukuran kinerja yang berbentuk prisma yang di sebut faset yang saling terkait yang dapat menciptakan kerangka kerja yang komprehensif dan terintegrasi untuk 


\section{Journal of Software Engineering Ampera}

Vol. 1, No. 1, February 2020 e-ISSN: 2775-2488

https://journal-computing.org/index.php/journal-sea/index

mengolah kinerja organisasi dan menjawab pertanyaan-pertanyaan terkait serta membangun sebuah medel kinerja bisnis yang terstruktur, pengukuran menggunakan merode TRADE untuk menghitung variabel-variabel dalam TRADE dan kecepatan kinerja sistem, dengan pengukuran ini dapat menghasilkan evaluasi kinerja sistem dan membantu memberikan rekomendasi usulan perbaikan yang tepat, selain itu dapat melakukan tingkat kepuasan dan penggunaan kinerja sistem melalui kuesioner dengan SPSS sebagai pengukurannya.

Dalam melakukan analisis kinerja sistem pada penelitian ini menggunakan metode Training Resources Data Exchange (TRADE) digunakan untuk membantu dalam pengembangan, pemanfaatan, evaluasi, dan interpretasi teknik dan alat pengukuran kinerja untuk mendukung manajemen operasi yang efisien dan efektif. metode TRADE adalah tahap-tahap pengukuran kinerja sistem yaitu identifikasi proses, identifikasi akrivitas krisis, menetapkan sasaran atau standar kinerja, menetapkan ukuran kinerja, identifikasi penanggung jawab, koleksi data, analisi atau pelaporan kinerja aktual, perbandingan kinerja aktual terhadap sasaran, usulan perbaikan. Ukuran kinerja sistem yang digunakan menurut TRADE (1995) adalah: Efektivitas (Effectiveness), Efisiensi (Efficiency), Kualitas (Quality), Ketepatan Waktu (Timeliness), Produktivitas (Productivity), Keamanan (Safety). Berdasarkan permasalahan diatas, maka akan dilakukan penelitian tentang Analisis Kinerja Sistem Informasi Akademik Menggunakan Metode Training Resources Data Exchange (TRADE) Pada Universitas Tridinanti Palembang.

\section{METODOLOGI PENELITIAN}

Metode penelitian yang digunakan dalam penelitian ini adalah metode deskriptif merupakan metode penelitian yang digunakan untuk menggambarkan masalah yang terjadi pada masa sekarang atau sedang berlangsung, bertujuan untuk mendeskripsikan apa-apa yang terjadi sebagaimana semestinya pada saat penelitian dilakukan. Metode Deskriptif adalah penelitian yang dilakukan untuk mengetahui nilai variabel mandiri, baik satu variabel atau lebih (independen) tanpa membuat perbandingan atau menghubungkan antara variabel satu dengan variabel yang lain, data kualitatif adalah data yang dinyatakan dalam bentuk kata, kalimat, dan gambar(Sugiono, 2016). 


\section{Journal of Software Engineering Ampera}

Vol. 1, No. 1, February 2020 e-ISSN: 2775-2488

https://journal-computing.org/index.php/journal-sea/index

\subsection{Pengukuran Kinerja Menggunakan TRADE}

Training Resources Data Exchange (TRADE) adalah tahapan pengukuran kinerja sistem bertujuan untuk membantu dalam pengembangan, pemanfaatan, evaluasi, dan interpretasi teknik dan alat pengukuran kinerja untuk mendukung manajemen operasi yang efisien dan efektif untuk tujuan internal perusahaan. TRADE di gunakan untuk mengetahui kinerja sistem secara menyeluruh melihat tingkat kepentingan dari aspek-aspek yang di ukur. untuk mengetahui kinerja sistem, maka dapat di lakukan dengan melalui tahapan-tahapan pengukuran kinerja sistem pada metode TRADE(Venita, 2016). Jaringan Training Resources Data Exchange (TRADE) dikelola oleh Oak Ridge Institute for Science and Education. Institut Sains dan Pendidikan Oak Ridge (ORISE) didirikan oleh Departemen Energi AS untuk melakukan program nasional dan internasional dalam pendidikan sains dan teknik, sistem pelatihan dan manajemen, sistem energi dan lingkungan, dan ilmu kedokteran. ORISE dan programnya dioperasikan oleh Oak Ridge Associated Universities (ORAU) melalui kontrak manajemen dan operasi dengan Departemen Energi AS. Didirikan pada tahun 1946, ORAU adalah konsorsium 88 perguruan tinggi dan universitas(Anderson, 1995).

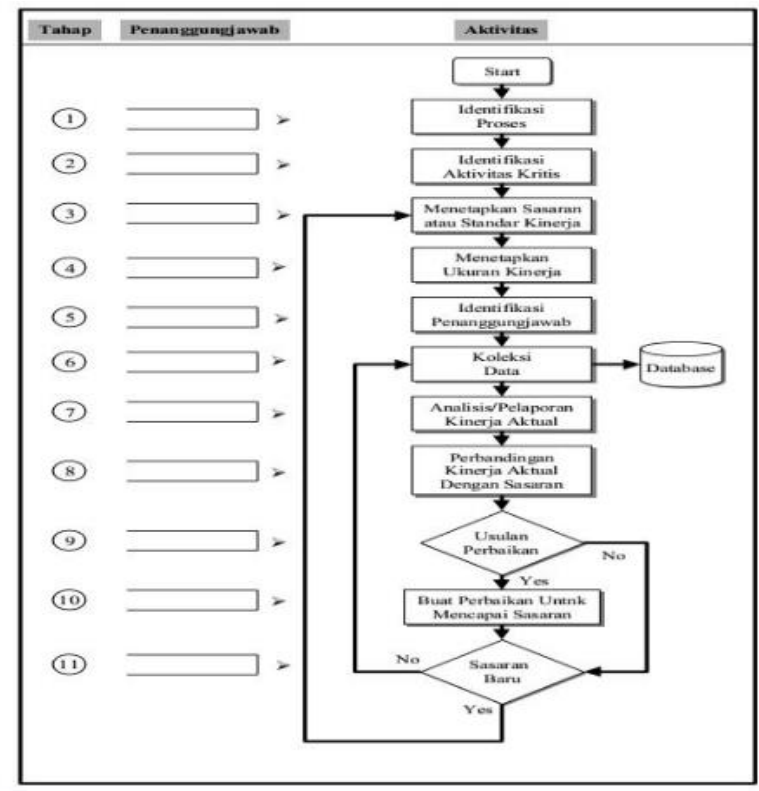

Gambar 1. Tahapan Tahapan Metode TRADE

(Sumber : A Handbook Of Techiques and Tools, 1995) 


\section{Journal of Software Engineering Ampera}

Vol. 1, No. 1, February 2020 e-ISSN: 2775-2488

https://journal-computing.org/index.php/journal-sea/index

1) Tahap Identifikasi Proses

Tujuannya untuk memahami proses-proses dalam sistem yang akan diukur. Sebagian besar upaya kita akan sia-sia jika tidak memulai dengan suatu proses yang terdefinisi dengan baik. Sehingga dalam melakukan suatu kontrol terhadap suatu proses maka kita perlu benar-benar memahami proses tersebut. Flow diagram / flow chart merupakan salah satu alat bantu (tools) yang dapat digunakan untuk memahami alur suatu proses dalam sistem. Suatu proses mungkin perlu diperinci dalam level- level sub-proses. Kemudian dari beberapa proses yang ada, perlu dipilih atau ditentukan proses mana saja yang akan di ukur.

2) Tahap Identifikasi Aktivitas Kritis

Aktivitas kritis merupakan suatu aktivitas/kegiatan yang memberikan dampak signifikan terhadap efisiensi, efektivitas, kualitas, ketepatan waktu, produktivitasatau keamanan suatu sistem. Pada level manajemen, aktivitas kritis akan menentukan prioritas manajemen, sasaran internal dan eksternal organisasi. Memilih aktivitas kritis untuk diukur merupakan hal sangat penting dalam upayamelakukan kontrol.

\section{3) Tahap Menetapkan Sasaran atau Standard Kinerja}

Sasaran dan standar suatu kinerja merupakan hal yang sangat penting.Sasaran selain dapat memberikan petunjuk bagi level manajemen, juga dapat menghimpun berbagai respon pada kebutuhan pengguna.Untuk setiap aktivitas kritis yang terpilih untuk diukur, sangat penting untuk menetapkan sasaran atau standar kinerjanya. Sasaran kinerja ditetapkan pada output dari semua proses atau pada aktivitas kritis yang menghasilkan output. Dalam suatu kenyataan, jika suatu sasaran/standar kinerja baru pertama kali ditetapkan dan tidak ada sasaran/standar sebelumnya maka kegiatan awal dalam obeservasi ini adalah menetapkan sasaran atau standar tersebut. Hal ini sangat mendasar karena pengukuran kinerja pada dasarnya tidak sekedar untuk mengetahui kinerja namun juga membandingkan kinerja sekarang dengan kinerja sebelumnya.

\section{4) Tahap Menetapkan Ukuran Kinerja}

Tahap ini melibatkan beberapa aktivitas yang dibutuhkan dalam pengukuran kinerja sistem.Setiap pengukuran kinerja memuat unit pengukuran yang terdefinisi, dokumentasi data, dan frekuensi dimana pengukuran dilakukan. 


\section{Journal of Software Engineering Ampera}

Vol. 1, No. 1, February 2020 e-ISSN: 2775-2488

https://journal-computing.org/index.php/journal-sea/index

5) Tahap Identifikasi Penanggung Jawab Unit

Pada tahapan ini, tim penilai kinerja menentukan siapa yang bertanggung jawab pada masing-masing aktivitas. Pihak / orang yang ditunjuk menjadi penanggung jawab, minimal harus mengetahui apa tujuan yang akan dicapai pada aktivitas yang dibidanginya, mengetahui kinerja aktual dan mempunyai otoritas untuk melakukan perubahan-perubahan seperlunya apabila kinerja aktual tidak sesuai dengan sasaran dan standar.

6) Tahap Koleksi Data

Data merupakan himpunan/kumpulan fakta yang direpresentasikan secara kuantitaif atau bentuk deskripsi.

7) Tahap Analisis/ Pelaporan Kinerja Aktual

Sebelum pengambilan kesimpulan dilakukan, kita peril melakukan verifikasi berdasarkan data yang sudah dikumpulkan.

8) Perbandingan Kinerja Aktual dengan Sasaran

Untuk mengetahui apakah kinerja aktual berdasarkan data/ informasi yang diperoleh sesuai dengan sasaran/standar yang ditetapkam atau terdapat penyimpangan.

9) Usulan Perbaikan

Tahap ini merupakan tahap pengambilan keputusan.Dimana peneliti harus memberikan usulan perbaikan pada sistem di perusahaan tersebut.

10) Membuat Laporan Hasil Analisis

Laporan Hasil Analisi merupakan hasil dari analisis dari kinerja sistem informasi akademik yang peneliti lakukan.

\subsection{Populasi Dan Sampel}

\subsubsection{Populasi}

Populasi dari penelitian ini adalah Mahasiswa dan Dosen Universitas Tridinanti Palembang

\subsubsection{Sampel}

Peneliti menggunakan rumus slovin sedangkan untuk taraf signifikasi (d) didasarkan atas pertimbangan peneliti artinya boleh dipilih apakah 0,01 (1\%) atau 0,05 (5\%) atau 0.1(10\%) (Riadi, 2016). Jadi dalam penelitian ini digunakan taraf siginifikasi sebesar 5\% dari total populasi sebanyak 4684 maka 


\section{Journal of Software Engineering Ampera}

Vol. 1, No. 1, February 2020 e-ISSN: 2775-2488

https://journal-computing.org/index.php/journal-sea/index

didapatkan jumlah sampel sebanyak 368 sampel. Berikut penghitungannya menggunakan rumus Slovin

Diketahui :

$$
\begin{aligned}
\mathrm{n} & =\frac{\mathrm{N}}{1+\left(\mathrm{N} \mathrm{x} \mathrm{e}^{2}\right)} \\
\mathrm{N} & =4450+234=4684 \\
& \mathrm{e}=5 \%(0,05) \\
\mathrm{n} & =\frac{\mathrm{N}}{\mathrm{N}(\mathrm{E})^{2}+1}=\frac{4450}{4450(0,05)^{2}+1}=\frac{4450}{12,125}=367,01=368 \text { Sampel }
\end{aligned}
$$

Teknik pengambilan sampel yang digunakan adalah probability sampling dengan jenis proportionade stratified random sampling. Alasan teknik ini digunakan adalah karena dapat memperkecil error, meningkatkan peluang setiap strata yang terwakili dalam sampel, selain itu juga agar mendapatkan ketepatan yang lebih tinggi, karena stratifikasi akan menghasilkan akurasi yang baik dalam melakukan penilaian terhadap populasi. Strata yang dimaksud ditentukan berdasarkan kedudukan yaitu mahasiswa dan dosen. Berikut dijelaskan perhitungannya:

Mahasiswa $=\frac{\text { Jumlah Populasi Mahasiswa }}{\text { Total Seluruhnya }} \times$ Jumlah Sampe

$$
=\frac{4450}{4684} \times 367=348,66=349 \text { Sampel }
$$

Dosen $=\frac{\text { Jumlah Populasi Dosen }}{\text { Total Seluruhnya }} \times$ Jumlah Sampel

$$
=\frac{234}{4684} \times 367=18,33=19 \text { Sampel }
$$

Jadi, jumlah sampel untuk mahasiswa adalah 349 sampel dan dosen adalah 19 sampel.

\section{HASIL DAN PEMBAHASAN}

\subsection{Variabel Effectiveness}

Setelah menghitung distribusi frekuensi, maka dilakukan analisis dengan metode Likert untuk mendapatkan range kategori Adapun range kategori variabel Effectiveness dapat dilihat pada Tabel 1 dibawah ini: 


\section{Journal of Software Engineering Ampera}

Vol. 1, No. 1, February 2020 e-ISSN: 2775-2488

https://journal-computing.org/index.php/journal-sea/index

Tabel 1 Range Variabel Effectiveness

\begin{tabular}{lllllc}
\hline & STB & TB & CB & B & SB \\
\hline 0 & $20 \%$ & $40 \%$ & $60 \%$ & $80 \%$ & $100 \%$ \\
& & & & \multicolumn{2}{c}{$\downarrow$} \\
& & & & $93,23 \%$ \\
\hline
\end{tabular}

Berdasarkan Tabel 1 diketahui bahwa dari 368 responden sebesar 93,23\% menyatakan sangat baik, artinya kinerja sistem informasi akademik sudah sangat baik menurut penggunanya dalam Variabel Effectiveness pada Universitas Tridinanti Palembang.

\subsection{Variabel Efficiency}

Setelah menghitung distribusi frekuensi, maka dilakukan analisis dengan metode Likert untuk mendapatkan range kategori Adapun range kategori variabel Efficiency dapat dilihat pada Tabel 3.2 dibawah ini:

Tabel 2 Range Variabel Efficiency

\begin{tabular}{llllll}
\hline & STB & TB & CB & B & SB \\
\hline 0 & $20 \%$ & $40 \%$ & $60 \%$ & $80 \%$ & $100 \%$ \\
& & & & \multicolumn{1}{c}{} \\
& & & & $92,70 \%$ \\
\hline
\end{tabular}

Berdasarkan Tabel 2 diketahui bahwa dari 368 responden sebesar 92,70\% menyatakan sangat baik, artinya kinerja sistem informasi akademik Universitas Tridinanti Palembang, menurut variabel Efficiency sudah memenuhi kinerja system

\subsection{Variabel Quality}

Setelah menghitung distribusi frekuensi, maka dilakukan analisis dengan metode Likert untuk mendapatkan range kategori. Adapun range kategori variabel Quality dapat dilihat pada Tabel 3 dibawah ini: 


\section{Journal of Software Engineering Ampera}

Vol. 1, No. 1, February 2020 e-ISSN: 2775-2488

https://journal-computing.org/index.php/journal-sea/index

Tabel 3. Range Variabel Quality

\begin{tabular}{lllllc}
\hline & STB & TB & CB & B & SB \\
\hline 0 & $20 \%$ & $40 \%$ & $60 \%$ & $80 \%$ & $100 \%$ \\
& & & & \multicolumn{2}{c}{$\downarrow$} \\
& & & & $93,04 \%$ \\
\hline
\end{tabular}

Berdasarkan Tabel 3 diketahui bahwa dari 368 responden sebesar 93,04\% menyatakan sangat baik, artinya kinerja sistem informasi akademik Universitas Tridinanti Palembang, menurut variabel Quality sudah memenuhi kinerja sistem.

\subsection{Variabel Timeliness}

Setelah menghitung distribusi frekuensi, maka dilakukan analisis dengan metode Likert untuk mendapatkan range kategori. Adapun range kategori variabel Timeliness dapat dilihat pada Tabel 3.4 dibawah ini:

Tabel 4 Range Variabel Timeliness

\begin{tabular}{lllllc}
\hline & STB & TB & CB & B & SB \\
\hline 0 & $20 \%$ & $40 \%$ & $60 \%$ & $80 \%$ & $100 \%$ \\
& & & & \multicolumn{2}{c}{} \\
& & & & $93,70 \%$ \\
\hline
\end{tabular}

Berdasarkan Tabel 4 diketahui bahwa dari 368 responden sebesar 93,70\% menyatakan sangat baik, artinya kinerja sistem informasi akademik Universitas Tridinanti Palembang, menurut variabel Timeliness sudah memenuhi kinerja sistem.

\subsection{Variabel Productivity}

Setelah menghitung distribusi frekuensi, maka dilakukan analisis dengan metode Likert untuk mendapatkan range kategori. Adapun range,kategori variabel Productivity dapat dilihat pada Tabel 5 dibawah ini: 


\section{Journal of Software Engineering Ampera}

Vol. 1, No. 1, February 2020 e-ISSN: 2775-2488

https://journal-computing.org/index.php/journal-sea/index

Tabel 5 Range Variabel Productivity

\begin{tabular}{lllllc}
\hline & STB & TB & CB & B & SB \\
\hline 0 & $20 \%$ & $40 \%$ & $60 \%$ & $80 \%$ & $100 \%$ \\
& & & & \multicolumn{2}{c}{} \\
& & & & $91,16 \%$ \\
\hline
\end{tabular}

Berdasarkan Tabel 5 diketahui bahwa dari 368 responden sebesar 91,16\% menyatakan sangat baik, menurut variabel Productivity artinya kinerja sistem informasi akademik Universitas Tridinanti Palembang sudah memenuhi kinerja sistem.

\subsection{Variabel Sefety}

Setelah menghitung distribusi frekuensi, maka dilakukan analisis dengan metode Likert untuk mendapatkan range kategori. Adapun range kategori variabel Safety dapat dilihat pada Tabel 6 dibawah ini:

Tabel 6 Range Variabel Safety

\begin{tabular}{|c|c|c|c|c|c|}
\hline & STB & TB & CB & $B$ & SB \\
\hline 0 & $20 \%$ & $40 \%$ & $60 \%$ & $80 \%$ & $\begin{array}{r}100 \% \\
\downarrow \\
\mathbf{\downarrow} \\
92,56 \%\end{array}$ \\
\hline
\end{tabular}

Berdasarkan Tabel 3.6 diketahui bahwa dari 368 responden sebesar 92,56\% menyatakan sangat baik, artinya kinerja sistem informasi akademik Universitas Tridinanti Palembang, menurut variabel Safety sudah memenuhi kinerja sistem.

\subsection{Pembahasan}

Berdasarkan kesimpulan metode TRADE (Trianing Resources Data Exchange) metode perhitungan sebagai berikut :

1) Variabel Effectiveness Kinerja Aktual= 93,23\% Maka Variabel Effectiveness memenuhi kinerja sistem informasi karena sudah melebihi standar yang sudah ditentukan 90\% maka sistem Informasi akademik univesitas Tridinanti Palembang kinerjanya sangat baik. 


\section{Journal of Software Engineering Ampera}

Vol. 1, No. 1, February 2020 e-ISSN: 2775-2488

https://journal-computing.org/index.php/journal-sea/index

2) Variabel Efficiency dengan Kinerja Aktual $=92,70 \%$ Variabel Efficiency sudah memenuhi kinerja sistem melebihi 90\% maka sistem informasi akademik menurut Variabel ini sudah sangat baik.

3) Variabel Quality, Kinerja Aktual $=93,04 \%$ Variabel Quality diatanyakan sangat baik sudah melebihi standar kinerja sistem.

4) Variabel Timeliness, Kinerja Aktual $=93,70 \%$ Variabel Timeliness sudah memenuhi kinerja sistem Sangat baik dalam sistem informasi akademik Universitas Tridinanti

5) Variabel Productivity Kinerja Aktual= 91,16\% Maka Variabel Productivity memenuhi kinerja sistem informasi karena sudah melebihi standar yang sudah ditentukan 90\% maka sistem Informasi akademik Univesitas Tridinanti Palembang kinerjanya sangat baik.

6) Variabel Safety, Kinerja Aktual $=92,56 \%$ Variabel Safety diatanyakan sangat baik sudah melebihi standar kinerja sistem Sistem Informasi Akademik Universitas Tridinanti Palembang.

\section{KESIMPULAN}

Berdasarkan penelitian yang telah dilakukan maka penelitian dapat mengambil kesimpulan :

1) Berdasarkan hasil penelitian kinerja sistem informasi akademik Universitas Tridinanti meliputi variabel Effetiveness, Efficiency, Quality, Timeliness, Productivity, Safety semuanya memenuhi standar kinerja sistem dengan Kinerja Aktual tertinggi adalah 94,13\% pada variabel Quality sangat baik dan terendah pada variabel Productivity dengan kinerja aktual adalah 91,15\% tetapi sudah memenuhi standar kinerja, sehingga sistem informasi akademik universitas Tridinanti dapat dikatan sangat baik menurut para pengguna sistem informasi dan pada setiap variabel pengukuran kinerja sistem semuanya sudah memenuhi standar Kinerja.

2) Pada variabel Effectiveness Kinerja Aktual adalah 93,23\% Maka Variabel Effectiveness memenuhi kinerja sistem informasi, pada Variabel Efficiency dengan Kinerja Aktual adalah 92,70\% variabel Efficiency sudah memenuhi kinerja sistem melebihi 90\% maka sistem informasi akademik menurut Variabel ini sudah sangat baik, pada variabel Quality, Kinerja Aktual adalah 94,13\% Variabel Quality diatanyakan sangat baik sudah melebihi standar kinerja sistem, pada variabel Timeliness, Kinerja Aktual adalah 93,70 \% variabel Timeliness sudah memenuhi kinerja sistem Sangat baik dalam sistem informasi, variabel Productivity Kinerja Aktual 


\section{Journal of Software Engineering Ampera}

Vol. 1, No. 1, February 2020 e-ISSN: 2775-2488

https://journal-computing.org/index.php/journal-sea/index

adalah 91,15\% maka variabel Productivity memenuhi kinerja sistem informasi dan variabel Safety, Kinerja Aktual adalah 94,04\% Variabel Safety diatanyakan sangat baik sudah melebihi standar kinerja sistem Sistem Informasi Akademik Universitas Tridinanti Palembang.

\section{DAFTAR PUSTAKA}

Anderson, A. et A. (1995). A Handbook Of Techquenes and Tools. Oak Ridge Associationted Universities (OROU).

Jogiyanto, H. (2008). Analisis dan desain. Yogyakarta. In Sistem Informasi Manajemen Jogiyanto H.M. Analisa dan Desain.

Riadi, E. (2016). Statistika Penelitian (Analisis Manual dan IBM SPSS). In Statistika Penelitian (Analisis Manual dan IBM SPSS).

Sugiono. (2016). Metode Penelitan Kuantitatif, kualitatif dan R\&D. In Bandung: Alfabeta.

Venita, A. (2016). Analisis Proses Reengineering untuk Mengukur Kinerja Sistem Informasi E-Filling Menggunakan Metode TRADE (Studi Kasus Kantor Pelayanan Pajak Pratama Semarang Barat). 1 No 2, 153-166. 